\title{
Collaborative Governance in Recognizing Customary Law Communities And Customary Communal Land Rights in Kampar Regency
}

\author{
Rury Febrina ${ }^{1}$, Raja Muhammad Amin ${ }^{2}$, Isril ${ }^{3}$, Ishak ${ }^{4}$ \\ 1,2,3,4 Government Science Department, Faculty of Social and Political Science, Universitas Riau, Indonesia, \\ Kampus Bina Widya, Jalan HR Soebrantas Km 12,5, Riau 28293 \\ Corresponding Author: rury.febrina@lecturer.unri.ac.id \\ doi https://doi.org/10.18196/igpp.v8i2.11104
}

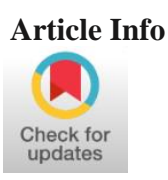

Article History;

Received:

2021-04-06

Revised:

2021-05-05

Accepted:

2021-06-14

\begin{abstract}
Recognition and protection towards customary law communities in Kampar Regency are inevitable, remembering that the existence of these communities far before the establishment of this nation. Kampar Regency issued a progressive response by Forming Registration Team for The Establishment of Customary Law Communities, Customary Territory, and Customary Forests in Kampar Regency. The Registration Team came from local government organizations, national land agencies, academicians, ministries, nongovernmental organizations, and customary community institutions that involve state actors. This collaboration successfully initiated the acknowledgment toward customary law communities and customary law with the release of the Regent Decree in some areas under the Kampar Regency. This study used a qualitative method with the type of phenomenological research. The results showed that collaborative governance initiated by NGOs focusing on the environment and sustainable development was not yet optimal. There is still domination in the tasks, unequal power/authority possessed by all parties, especially local governments, conflicts of interest are more on the clan. Regarding HGU, the replacement of regional heads, which affects political will on MHA, and communication and coordination issues across sectors are still the main obstacles.
\end{abstract}

Keyword: Collaborative Governance; Customary Law Communities; Customary Communal Land; Kenegerian.

\section{INTRODUCTION}

The recognition toward the customary law community is highly related to the customs in Indonesia and the traditions of customary law in Indonesian society. Customary laws have few elements within them, such as unwritten law. It consists of terms and conditions of Indonesian customs rooted in Indonesian cultural values. History must adapt to changes (grow and spread in the society), obeyed and respected by the community due to its consequences (sanctions).

Customary law communities and lands share a close relationship between one and another. The law relation between customary law communities and their lands created a right that gives these communities lawful group rights to utilize the lands for their benefit. It is the original and primary right in customary communal land law. It covers all lands under the customary law communities, which are also considered rights upon another land under the environment of customary law communities and can be owned by all community members. The said lands are customary communal land rights, including the asset of villages. According to Boedi Harsono in (Salamat, 2016) communal land rights of customary law community is determined by three 
aspects:

1. The groups to a particular customary law group, which is a customary law community

2. The area communally owned by the said customary law communities and recognized as communal belongings of the communities as its lebensraum

3. The customary leaders recognized by the said customary law communities and do their daily activity as the executor of customary land rights

Based on the three points above, cumulative criteria (not alternative) are absolute to determine whether the communal land rights still exist. Therefore, if one out of three elements cannot be fulfilled, there will be no more communal land rights. The state and the government must acknowledge and protect customary law communities and communal land rights. Indonesian Ministry of Home Affairs Regulation No. 52 of 2014 about Guidelines in Recognizing and Protecting Customary Law Communities Article 2 mentions that Governor and Regent/mayor acknowledge and protect customary law communities. In that regulation, the acknowledgment toward communal lands and customary law community is given by creating regional government decree. One of the few issues to be identified is customary law communities or social groups.

Customary communal land rights are a set of obligations and authority of a customary law community regarding the land under their territory. Communal land rights consist of two elements: the element of belonging that includes civil law and authority to regulate ownership and lead authority duties, including public law authority. The part of authority has public law in practice to be bestowed upon the leader of customary law communities or alongside the elders of the said customary law communities. In Riau Province, there is still acknowledgment towards land under the territory of customary law communities. The management, authority, and usage are based on the terms and conditions of local customary law communities and recognized by the said communities as their communal land. However, it does not mean it is free from problems.

The communal land, determining and deciding communal land, utilization, and ownership of communal land, registering communal land, and settlement of conflicted communal land has been regulated by Riau Province's Regional Government Regulation Number 10 of 2015 about Communal Land Utilization. It explains that: "Communal lands holds a position as tribal or customary law communities' wealth that they gain from generation to generation. Tribe leaders that have govern the communal land are leaders who possess the rights upon each communal land. But the tribe leader who governs the land may not shift or remove their rights toward other parties unless done together based upon the discussion within the tribe members suitable with the existing tribe customs. Therefore, every tribe leader and customary law communities should control their utilization and ownership of their communal lands. So does the Regional Government's role, Regency or City, supervise communal land rights, like being mentioned in Kampar Regency Regional Regulation Number 12 of 1999 about Communal Lands Article 13. It says: "Regent Regional Leader is the protector of 'ninik mamak' and has consultative and development relation towards the progress of customary laws."

Kampar Regency is one of the regencies in Riau Province, Indonesia, that has a vast customary forest and has 21 districts. Moreover, Kampar Regency is also a potential location to manage customs-based resources. It indicates a possible spacious 203.000 ha of customary forest that spreads across its territory, Left Kampar, Right Kampar, and Downstream Kampar. The not optimal data gathering regarding communal land and the existence of customary law community is still an issue that makes not everything catered by the policy regarding the acknowledgment of customary law society and communal land. Customary law communities that live in simplicity are one of the customs' main traits.

A progressive response was given regarding the recognition toward customary law communities and communal land in Kampar Regency by Kampar Regent with releasing certain decrees such as Regent Decree Number 660LH-IV.2/32 of 2018 about Forming Registration Team in Establishing Customary Law Communities, Customary Territories, and Customary Forests in Kampar Regency. The collaboration that stresses the involvement of many elements can be seen from the existing composition within the registration team itself, such as government elements, non-governmental organizations, and customary communities, academicians as well as private parties in Table 1: 
Table 1. Registration Team in Establishing Customary Law Communities, Customary Territories and Customary Forests in Kampar Regency

\begin{tabular}{|c|c|c|}
\hline No. & Name/Position/Service & Position in team \\
\hline 1. & Kampar Regent & Director \\
\hline 2. & Vice Kampar Regent & Director \\
\hline 3. & Regional Secretary of Kampar Regency & Leader \\
\hline 4. & $\begin{array}{l}\text { Government and Society Welfare Assistant of Kampar Region } \\
\text { Secretariat }\end{array}$ & Vice Leader \\
\hline 5. & Economic and Development Assistant of Kampar Region Secretariat & Vice Leader \\
\hline 6. & Kampar Regency's Head of Environmental Services & Secretary \\
\hline 7. & $\begin{array}{l}\text { Kampar Regency's Head of Communities and Village Empowerment } \\
\text { Services }\end{array}$ & Member \\
\hline 8. & Kampar Regency's Head of Planning and Development Services & Member \\
\hline 9. & Kampar Regency's Head of Plantation and Farmery & Member \\
\hline 10. & Kampar Regency's Head of Public Works and Spatial Planning & Member \\
\hline 11. & Kampar Regency's Head of Tourism and Cultural Services & Member \\
\hline 12. & Head Division of Administration and Regional Secretariat & Member \\
\hline 13. & Head Division of Regional Secretariat Law and Human Rights & Member \\
\hline 14. & $\begin{array}{l}\text { Head Office of Agrarian Affairs and Spatial Planning/National Land } \\
\text { Agency }\end{array}$ & Member \\
\hline 15. & Head of KPHP Model Kampar Kiri & Member \\
\hline 16. & Head of UPT KPH Suligi-Batu Gajah & Member \\
\hline 17. & All Head Districts in Kampar Regency & Member \\
\hline 18. & Head of Customary Institutions in Kampar Regency & Member \\
\hline 19. & Head of AMAN Kampar & Member \\
\hline 20. & Director of Pelopor Sehati Foundation & Member \\
\hline 21. & WRI Indonesia & Member \\
\hline 22. & Dr. Elviriadi, S.Pi, M.Si (Academician of UIN Suska) & Member \\
\hline 23. & Darmadi, S.Pd, M.Si (Academician of Riau University) & Member \\
\hline
\end{tabular}

Source: Attachment in Regent Decree Number 660LH-IV.2/32 of 2018 about Registration Team in Establishing Customary Law Communities, Customary Territories and Customary Forests in Kampar Regency

The Registration Team for the Establishing of the Customary Law Communities has successfully initiated the release of a decree from the Regent of Kampar on the recognition of the customary law communities and the communal land rights of several states in Kampar Regency in 2019, including:

a. Kampar Regent's Decree Number: 660-490 / X / 2018 About Communities Recognition of Customary Law Communities and Communal Land Rights Kenegerian Batu Songgan Kekhalifahan Batu Songgan Batu Songgan Village Kampar District Kiri Hulu Kampar Regency.

b. Kampar Regent's Decree Number: 660 - 489 / X / 2018 About the Recognition of Customary Law Communities and Communal Land Rights Kenegerian of the Gajah Bertalut Kekhalifahan Batu Songgan Gajah Bertalut Village District Kampar Kiri Hulu Kampar Regency.

c. Kampar Regent's Decree Number: 660 - 491 / X / 2018 About Public Recognition of Petapahan Customary Law and Recognition of Imbo Putui Indigenous Forest Petapahan Petapahan Village, Tapung District, Kampar Regency.

d. Kampar Regent's Decree Number: 660 - 326 / IV / 2019 About the Recognition of Customary Law Communities and Communal Land Rights in Kenegerian Aur Kuning Kekalifahan Batu Songgan Desa Aur Kuning Kampar Kiri Hulu District Kampar Regency.

e. Kampar Regent's Decree Number: 660 - 327 / IV / 2019 About the Recognition of Customary Law Communities and Communal Land Rights in Kenegerian Terusan Kekhalifahan Batu Songgan Terusan Village Kampar Kiri Hulu District Kampar Regency. 
f. Kampar Regent's Decree Number: 660 - 328 / IV / 2019 About Recognition of Kampa State Customary Law Communities and Recognition of Ghimbo Boncah Lidah and Ghimbo Pomuan Indigenous Forest and Ghimbo Pomuan Kenegerian Kampa, Kampa Village and Koto Village Perambahan Kampa Subdistrict Kampar Regency.

g. Kampar Regent's Decree Number: 660 - 325 / IV / 2019 About the Recognition of Customary Law Community and Communal Land Rights of Persukuan Petopang Kenegerian Kuok Desa Bukit Melintang Kuok District Kampar Regency.

This progressive response is an initial step that is considered strategic in protecting customary law communities and communal land rights. Based on the technical guidelines prepared by the registration team, there are provisions in the draft to apply for zoning, customary communities, and customary forests in Kampar Regency through several activities, namely as follows:

1. Conduct participatory mapping of customary forests territory,

2. Meet the local people in managing customary forests in a sustainable manner,

3. Establish customary forest management institutions,

4. Write down the history and customary rules regarding customary-based natural resource management,

5. Communicate and coordinate with the regional, central, provincial, and district governments for proposing customary forests.

The attention collaboration could lead to thinking that it represents a fundamental shift in how government and public-sector organizations operate. The collaboration era has, or will soon, arrive: a collaborative turn has occurred (O'Flynn, 2008). The coordination and communication to recognize customary law communities and customary communal land involve the communities, the central government, and local governments. NGOs that have previously carried out mentoring and empowerment in Kampar Regency, especially NGOs, focus on environmental issues, both in the work area of Riau and the national level. NGOs' role can be the main initiators of this recognition which are also part of the registration team. This collaboration model is interesting to study considering the Customary Law Society and the potential for customary communal land to be initiated by non-state actors who play an essential role and become key actors in getting the government's recognition.

According to (Ansell \& Gash, 2008), the governance process is familiar with collaborative governance (Maulana Mukhlis, Nasrullah Nazsir, Mudiyati Rahmatunnisa, 2018). "The process of government governance and public policy is called using the collaborative governance when it is characterized with six elements; the initial role of the government, the entering of non-state actors, mutual decision making, formal organizing, obtaining consensus. There is an issue to collaborate both concerning policy and public service." Besides, according to Davis and Keating (2002) quoted by (Maulana Mukhlis, Nasrullah Nazsir, Mudiyati Rahmatunnisa, 2018) states that:

"The good governance concept explains how the government governance system runs with wider role scopes, not only including the government alone but also including non-government organizations and civilians. It means that the interactions between actors (government and nongovernment organizations) in collaboration will contribute to the good governance realization."

The concept of good governance describes how the government system operates with a broader scope of roles, not only covering the government but also including non-governmental organizations and civilians. The interaction between actors (government and non-governmental organizations) in collaboration will contribute to good governance (Sepriandi \& Hussein, 2019). Empirically, the implementation of collaborative governance in various countries and regions of Indonesia has been widely used to produce policies. Most cases show that collaborative governance is an approach with positive implications for better outcomes. Collaborative governance can restore various policy pathologies in politicization of regulations, excessive or limited budgets, and failure of policy implementation (Dewi, 2012).

Collaborative governance is a complex structure where there are possible imbalances that may occur between stakeholders. Therefore, to gain consensus in decision-making, the role of a 
facilitator or public manager in balancing the power between stakeholders is needed. Even at this point, the role of power in collaboration still debatable, regarding where one actor cannot dominate, the balancing role, and the various interests of other actors (Wulandari et al., 2019).

According to Abdul Sabarudin (Adrie, 2018), collaboration means working together or cooperating with other parties. The individual actors, groups, or organizations work together in several businesses. Meanwhile, Rilley defined collaboration as a specific form of relationship between non-governmental organizations (those concerned with environmental issues and sustainable development) with government organizations. (Ansell \& Gash, 2008) also, try to define Collaborative Government as follows:

"A governing arrangement where one or more public agencies directly engage non-state stakeholders in a collective decision-making process that is formal, consensus-oriented, and deliberative and that aims to make or implement public policy or manage public programs or assets".

In other words, collaboration is an effort to make rules that regulate two or more institutions that take care of public affairs, either directly or indirectly. These institutions share an interest in handling non-state affairs. In carrying out collaboration, each party must have a formal relationship and have a solid commitment to what was agreed upon at the start. Each party is entirely entrusted with the duties while maintaining coordination in planning and implementing programs related to the public interest. Leaders in public affairs identify tools and instruments for the new governance through networks of public, private, and nonprofit organizations (Bingham et al., 2005).

Collaborative collaboration requires a shared vision and goals, strategies, and activities to achieve the goals. Even though in collaboration, each of the parties must equalize their vision, goals, strategies, and activities, each of them still has the authority to make decisions independently (Wulandari et al., 2019). The collaborative governance Framework integrated knowledge about individual incentives and various collective action collaborative social learning and conflict resolution process and institutional arrangements for cross-boundary collaboration (Emerson et al., 2012).

The Collaborative Governance model was developed by (Ansell \& Gash 2008) with several stages, such as starting conditions, facilitative leadership, institutional design, and collaborative process. In the starting condition, it is the stage of facilitating cooperation between existing stakeholders. There are two critical issues in this stage: the imbalance of resources owned by each stakeholder and incentives to participate. While at the facilitative leadership stage, it is critical to involve stakeholders in one unit to be closer to one another and unite them in one spirit. Next is the institutional design stage or designing a collaborative institution.

This institution is a fundamental rule of the game in the cooperation process, and the institution's nature must be open. The last stage is the collaborative process. The process in this collaboration is to build stages starting from the face-to-face dialogue oriented towards mutual agreement. Building trust between one another and a mutual commitment work together so that a common understanding can emerge. Only after all goes well will the outcomes be achieved as expected. Departing from the conditions above, the author needs to examine "Collaborative Governance in Acknowledging Customary Law Communities and Communal Land Rights in Kampar Regency, Riau Province, Indonesia".

\section{RESEARCH METHOD}

This research aims to identify and analyze Collaborative Governance in recognizing customary law communities and customary land in the Kampar Regency. In this research, the method used is qualitative. According to Bogdan and Taylor (Moleong, 2007), qualitative methods are research procedures that produce descriptive data in written or spoken words from people and observable behavior. The type of research was the phenomenology type and literature study. It is a research model to create a description/exposure and explore carefully and deeply certain 
social phenomena without intervention and hypotheses and measurements by utilizing literature in the form of books, articles/journals, mass media coverage, laws and regulations, and others.

In this study, in general, using two data collection techniques that were interrelated and complementary, such as in-depth interviews, in-depth interview techniques were done with informants. Besides, literature studies were also done by utilizing literature in books, articles/journals, mass media coverage, laws, and regulations.

\section{RESULT AND DISCUSSION}

The Constitution of the Republic of Indonesia regulates the existence and traditional rights of customary law communities that existed before the Indonesian state was founded. It is the state's responsibility to recognize, protect, advance, enforce, and fulfill indigenous peoples' rights to provide legal certainty and justice for indigenous peoples who are an integral part of the Republic of Indonesia.

Act No. 6 of 2014 concerning Villages seeks to strengthen the original composition of the customary law communities and restore the position of the customary law communities as a public legal entity that is part of the government and not outside the government. The principle of reconstruction is inherent in customary law communities with their original composition, a form of state recognition and respect for customary law units and their traditional rights (Amin et al., 2016). Government Regulation No. 52 of 2014 concerning Guidelines for the Recognition and Protection of Customary Law Communities regulates the recognition and protection of customary law communities by the Governor and the Regent / Mayor through the regional head and joint decrees if the customary law community is in two or more districts/cities.

However, the reality in the communities has not shown the recognition and protection, even the strengthening of agrarian conflicts due to legal uncertainty, which has an impact on the loss of access of indigenous peoples to their land, territory, and natural resources, damage to social structures and ecology. It becomes a necessity for recognition of customary law communities and their access to customary communal land as long as it is still alive, following community development, following the principles of the Republic of Indonesia, and is regulated in law (P.P et al., 2018).

Kampar Regency is one of the districts in Riau Province with an area of $\pm 1,128,928 \mathrm{H}$ and consists of 21 Districts and 250 villages/districts with a population (as of December 2018) reaching 851,837 people. The number of villages or other names in Riau Province, especially in Kampar Regency, called kenegerian, shows that Kampar has many indigenous peoples. The form of the Village/Kenegerian government is itself a customary law community.

The name better knows the customary law communities in Kampar Regency of Kenegerian, in which the Caliphate rules some states. However, since Act No. 5 of 1979 on Village Governance, some kenegerian have been abolished. Caliphate has also been canceled so that the status of government under the district is not kenegerian but replaced Village/ sub-district, then the Caliphate that had several kenegerian under it where it turned into a village directly below the District. Therefore, this condition also implies a government structure in the Kampar Regency (Asrida, Wan; Amin, Raja Muhammad; Marta, 2019).

There are few local regulations regarding the recognition and protection of Customary Law Communities and their traditional rights in some regions. In Riau Province, Regional Government Regulation Number 10 of 2015 concerns Communal Land and Its Utilization. While for city districts only in Kampar Regency, there is already a regional regulation that recognizes the communal land rights of the state's customary law communities, called Regional Regulation No. 12 of 1999 concerning communal land rights. Recognition of customary law communities must be comprehensively covered, covering their communities, customary territories, and traditional rights, containing customary forests or other names. Although Regional Regulation 12 of 1999 exists, this regulation only recognizes objects that are communal land rights in Kampar District, so it has not comprehensively fulfilled the constitution's mandate, called Article 18 B paragraph (2) of the 1945 Constitution (Syofyan, 2015). 
The Collaborative Governance approach related to recognizing customary law communities and customary land in Kampar Regency is one strategic approach used. It can be an example for other areas, especially in Riau Province.

The Collaborative Governance approach emphasizes several necessary prerequisites, including (1) Formation of forums initiated by the government, (2) Non-state actors involving in the forum, (3) All parties in the forum involving in decision making and not only as institutions/organizations asked for recommendations (consultative), (4) The collective and official meetings, (5) The orientation of the forum becoming a consensus in decision making, (6) The focus of the collaboration on public policy or public management. Also, the Collaborative Governance Model developed by Ansell and Gash consists of stages, namely starting conditions, facilitative leadership, institutional design, collaborative process with the following explanation (Ansell \& Gash, 2008):

\section{Starting Condition}

In the early stages, the starting condition is the initial stage of facilitating cooperation between stakeholders, considering the imbalance of the resources by the organization and the incentives to participate in this stage. If the resources and strengths owned by each stakeholder are not balanced, then the cooperation will be manipulated by stakeholders who have a lot of resources and power. Therefore, if that happens, there must be a commitment to help weaker stakeholders. Another issue that is no less important is the need for incentives so that more invalid stakeholders can persistently join forces to work together. Finally, there must be an anticipation of conflicts in cooperation so that at the beginning, trust must be built between one and another (Ansell \& Gash, 2008).

Recognition of customary law communities in Kampar District has been initiated by several NGOs that focus on environmental issues and sustainable development, together with academics integrated with the national program, namely the one map policy. The One Map Policy (OMP) is a Government policy to create a good forest and land governance to prevent land tenure conflicts in Indonesia. The OMP policy is in line with the spirit of agrarian reform, which is the government's priority program and is strengthened by Presidential Decree No.9 / 2016 concerning the Acceleration of the One Map Policy at the map accuracy level of 1: 50,000 scale (Silviana, 2019).

Organizations and NGOs involved in this initial stage include World Resource Institute (WRI) Indonesia, Bahtera Alam Riau, Pelopor Sehati Foundation, and the Kampar Indigenous Peoples Alliance (AMAN). This collaboration was initially intended to build communication with the local government regarding the recognition of customary law communities and customary communal land. The communication carried out was not without obstacles. There were concerns about conflicts such as claims against Cultivation Rights Title and others that were only oriented to economic aspects without paying attention to forests as a system and source of livelihood. In a collaborative governance framework, the factors that influence collaboration success include face-to-face dialogue, building trust, and developing mutual commitment and understanding. However, it cannot be actualized quickly due to its commitment and support for preserving natural resources and indigenous people.

In an expose conducted by the Regent of Kampar in 2019 regarding the process of recognizing customary law communities, customary territories, and customary forests, the background is that:

a. Communities-based forest management practices are still ongoing (Rumbio Customary Forest in Kenegerian Rumbio, Imbo Putui Traditional Forest in Kenegerian Petapahan, Bonca Lida Customary Forest, and Imbo Pomuan in Kenegerian Kampa) Khalifah Kuntu ${ }^{1}$ was fully involved in the Judicial Review process of Law No.41 of 1999, which changed the

\footnotetext{
${ }^{1}$ The Caliphate is a customary law community forum consisting of several countries. Kenegerian is a customary law community unit located in Kampar Regency. Datuak Khalifah is the leader of the Caliphate. Kuntu Caliphate led several to Kenegerian, namely to Kenegerian Kuntu, to KenegerianPadang Sawah and Kenegerian Domo.

130 | Rury Febrina ${ }^{1}$, Raja Muhammad Amin'2, Isril ${ }^{3}$, Ishak ${ }^{4}$
} 
context of Customary Forests from "State Forest to Private Forest" with the release of Constitutional Court Decree No. 35 of 2012 (Nusantara, 2012)

b. Regional Law Products related to communal land and Indigenous People (Kampar District Regional Regulation No.12 of 1999 concerning communal land)

c. The Great Potential of Customary Forests in Kampar District

d. Activists and supporters of indigenous communities (WRI. Pelopor Sehati Foundation and AMAN Kampar)

Based on these exposures, there is a long history of recognizing legal communities, customary areas, and customary law in the Kampar Regency. The collaboration, which began in 2017, received support from the then Kampar Regent, namely Mr. Aziz Zainal, with the Regional Secretary and several Regional Offices Heads. Face-to-face dialogue is carried out in a marathon with NGOs to build trust and equalize perceptions regarding related regulations/policies, areas that have the potential for further study, and reaching an agreement to form an Accelerated Team or Registration Team for the Determination of Indigenous Peoples.

Based on the explanation above, in the initial conditions, the initiation of collaboration initiated by NGOs / NGOs with indigenous people is still not optimal even though MHA and the potential for community-based management in Kampar District are still strong. It is indicated by the slow response received from the local government and the potential for conflict. The support of local governments in efforts to conserve natural resources and customary law communities is still minimal, thus affecting the length of the coordination and consultation process built from 2017 until it was realized in 2019-2020. This initial condition shows that the Kampar Regency Regional Regulation Number 12 of 1999 concerning Ulayat Land Article 13 is not yet optimal, which reads: "The Regent of the Regional Head is the protector of ninik mamak has a consultative relationship and fostering the development of customary law".

\section{Facilitative Leadership}

Facilitating leadership is a critical stage to involve stakeholders in one unit, get closer to one another, and unite them in one spirit. Also, leadership is significant in maintaining the game's rules in cooperation, building trust between one another, facilitating dialogue, and exploring mutual benefits (Ansell \& Gash, 2008). Practice for collaborative leadership includes the joint commitment to identify research, create a shared understanding of the achievement of stakeholder support, and establish trust (Silvia, 2011).

The Regulation of the Minister of Home Affairs of the Republic of Indonesia No. 52/2014 concerning Guidelines for the Recognition and Protection of Customary Law Communities in Article 2 states that the Governor and the Regent/Mayor recognize and protect indigenous people in the regional head decree. Also, there is a consultative relationship and fostering towards the development of customary law inherent in the duties of the local government as stated in the Kampar Regency Regional Regulation Number 12 of 1999 concerning Communal Land. The regent is the spearhead in accelerating this recognition. The Regent's decree is an actualization of the regional head's political will, which will affect the entire process/stage of recognition and development and development for indigenous peoples and customary rights in the Kampar Regency. The positive response received from the Kampar Regent was a strategic first step and was even followed up by visits to customary forests in several areas.

Besides, leadership in recognizing customary law communities in Kampar Regency can also be seen in the structure. The Customary Law Communities Determination Registration Team formed by the Regent and chaired by the regional secretary is strategic. The team consisted of elements from the Kampar Regional Offices, the land office, academics, aspects from the ministry in charge of environmental and forestry affairs, traditional institutions, and NGOs. In general, this team carries out the identification, verification, and validation of indigenous peoples, customary territories, and state forests, even further to the stage of ongoing assistance.

At the Facilitative Leadership stage, the collaboration built also strengthened local leadership, such as Kampar customary law communities or Datuak Pucuk Adat Kenegerian and Ninik Mamak Pesukuan and customary instruments in each kenegerian. Datuak pucuk adat/customary leaders and other stakeholders influence the proposal for the establishment/ 
recognition of customary law communities, customary areas, and customary forests. One of which is information related to Tumbo (a source of customary law passed down from generation to generation) and Ghimbo (kenegerian customary forest) and customary agreements needed to fulfill the requirements related to the sustainable management potential. Governments urgently need to provide enabling policy and legal frameworks and integrated program guidelines to actively promote recognition of legal communities, customary areas, customary law, indigenous governance capacity, and authority. Building Indigenous governance institutions and capacity should be built into any new interventions right from the start (Smith, 2008).

\section{Institutional Design}

Institutional design is a stage where a collaborative institution is designed from many elements. Institutional design can be seen when forming a structure or institution that can communicate and coordinate in making decisions and taking real action. Collaborative governance also implies that non-state/government stakeholders have responsibility for policy outcomes. The highest authority may lie upon public bodies or the government itself, but stakeholders must directly participate in the decision-making process (Ansell \& Gash, 2008).

The processes of public-sector collaborations often continue to reflect implicit hierarchical relationships between the actors (Shergold, 2008). The imbalance of power between stakeholders is a common problem noted in collaboration. Suppose some stakeholders do not have the capacity, organization, status, or resources to participate or to participate on an equal footing to other stakeholders. In that case, collaborative governance processes will be vulnerable to manipulation by stronger actors. The incentive to participate in collaborative governance will also increase if stakeholders perceive that the achievement of their goals depends on the cooperation of other stakeholders.

Based on the Ministry of Home Affairs Regulation No. 52/2014 concerning guidelines for recognizing customary law communities, Article 3 states that in acknowledging and protecting customary law communities, the Regent/Mayor shall form a Regency/City Customary Law Communities Committee. The Regent of Kampar Regency has followed up by creating a committee/Team for the Registration of Customary Law Communities Determination through the Decree of the Kampar Regent No. 660/DLH-IV-2/32, which is in charge of carrying out identification, verification, and validation of customary law communities, customary territories, and kenegerian customary forests by observing the following aspects;

a. History and origins of indigenous people

b. Customary law that applies and is obeyed in the communities

c. Customary Law Communities Institutions

d. Procedures for resolving disputes and customary witnesses

e. Customary territory

f. Local wisdom of customary law communities in customary forest management

This registration team provides recommendations for establishing customary law communities, customary territories, and customary forests that the Regent will later determine through a Regent Decree. It is an optimal institutional design when viewed from its duties because not all elements are in the team, especially the local government is actively involved in all stages. Non-state actors or NGOs still dominate even the initiators' tendency to recognize and protect customary law communities in the Kampar Regency. Coordination and communication can be done not intensively, and conflicts of interest are also inevitable in this collaboration.

\section{Collaborative Process}

Building a dialogical stage between parties oriented towards mutual agreement correlates to strengthening mutual trust and mutual commitment to work together, leading to mutual understanding and achieving the expected results. The collaborative process can be seen in the process of determining the communities of customary law communities, customary territory, and customary law in Kampar Regency, which starts from:

a) Socialization of Accelerated Designation of Customary Forests, Registration System for Customary Law Communities, and Establishment of a Verification Team for Kampar District 
b) Forming a Registration Team for the Establishment of Customary Law Communities, Customary Areas and Customary Forests in Kampar Regency based on Regent Decree Number 660 / DLH-IV.2 / 32 April 30th, 2018

c) Coaching Clinic for the Registration Team for the Establishment of Customary Law Communities, Customary Areas, and Customary Forests in Kampar Regency

d) Suggestions from Indigenous Peoples, Customary Areas and Adat Forest Kenegerian Petapahan, Batu Sanggan, Gajah Bertalut, Kuok, Kampa, Aur Kuning and Terusan

e) Technical verification of the proposals of Customary Law Communities, Customary Areas and Customary Forests by the Registration Team for the Designation of Customary Law Communities, Customary Areas and Customary Forests in Kampar District

f) Determination of Customary Law Communities, Customary Areas and Customary Forests by the Regent through regional legal products (Regent Decree)

g) Recommendation for recognition and designation of customary forests to the Minister of Environment and Forestry of the Republic of Indonesia

h) Ministry of Environment and Forestry verification has been carried out for Kenegerian Petapahan and Kampa. Meanwhile, other proposals that are in forest areas will be carried out further by the Indonesian Ministry of Environment and Forestry

i) Designation of Customary Forests by the Minister of Environment and Forestry of the Republic of Indonesia

Based on the explanation, if integrated, there is a technical verification stage divided into the preparation and implementation stages of the customary law communities, customary territories, and customary law in Kampar Regency, seen in Table 2 and Table 3:

Table 2. Preparation Stages for the Establishment of Customary Law Communities, Customary Territory, and Customary Laws in Kampar Regency

\begin{tabular}{|c|c|c|}
\hline No. & Activity & Supporting Documents and Parties Involved \\
\hline 1 & $\begin{array}{l}\text { Consolidation Team to equalize } \\
\text { understanding, share roles in the Technical / } \\
\text { Vertex Verification process }\end{array}$ & Mapping, socio-culture, law, and ecology \\
\hline 2 & $\begin{array}{l}\text { Prepare and bring the application documents } \\
\text { for Customary Territories, Customary Law } \\
\text { Communities, and Customary Forest }\end{array}$ & $\begin{array}{l}\text { Consists of: } \\
\text { Application letter and attachments, such as: } \\
\text { proposed map, } \\
\text { region profile, } \\
\text { Communities law products } \\
\text { institutional, } \\
\text { charter agreement } \\
\text { other supporting documents } \\
\text { Letter of Task Order }\end{array}$ \\
\hline 3 & $\begin{array}{l}\text { Prepare, observe and bring documents of } \\
\text { administrative verification results }\end{array}$ & - \\
\hline 4 & $\begin{array}{l}\text { Create and send a letter of invitation for the } \\
\text { implementation of the FGD with the proposer }\end{array}$ & $\begin{array}{l}\text { The Proposer consists of: } \\
\text { Traditional figures, such as; Khalifah, Datuk Pucuk, } \\
\text { Ninik Mamak, Alim Ulama, Cerdik Pandai, Bundo } \\
\text { Kandung, and others } \\
\text { Village Head and village officials, } \\
\text { Local youth / young women, } \\
\text { Management of Customary Forest management } \\
\text { institutions, } \\
\text { Public figure } \\
\text { Field companion }\end{array}$ \\
\hline
\end{tabular}

Source: Standard Operational Procedure (SOP) Registration Team for the Establishment of Customary Territory, Customary Law Communities and Customary Forests in Carrying Out Technical Verification of Kampar Customary Forest

Based on the preparatory stages, verification involves many elements from both the registration team and the proposing party related to the completeness of requirements and directed communication patterns to verify administrative documents. The main obstacle at this 
stage is more on the readiness of the communities, especially the applicant in completing the requirements. It is where the role of the local government, together with NGOs and field assistants, to provide protection and legal certainty and fulfill the rights of indigenous people to access natural resources in their customary territories and the preservation of customary law. The next stage is the implementation stage, where the registration team carries out a series of activities that require abilities, especially those related to geospatial references seen in Table 3 .

The recommendations made by the registration team are a long process involving many parties. The steps taken resulted in the establishment of customary law communities and the proposal of the customary forest for the location of other use areas (APL) seen in Table 4. Based on Table 4 , the collaboration has succeeded in recognizing indigenous peoples, customary territories, and customary law in the Kampar Regency. The division of roles, especially non-state actors, is also carried out where NGOs collaborate in preparing pre-license letters such as preparing documents, participatory mapping, establishing and strengthening institutions, and making local legal frameworks. Organizations bring different resources and expertise, which creates a collaborative advantage (Huxham \& Vangen, 2008). The customary institutional affairs are managed by AMAN Kampar, while WRI and Bahtera Alam manage the participatory mapping and design. Academics are involved in making the legal umbrella. Also, there is a division to prepare assisted areas such as the Pelopor Foundation, which is more focused on preparation in the Kuok area, Aman in Batu Sanggan, Bahtera Alam in Petapahan. This division of roles and regions indicates a pattern of cooperation based on the capacity of each agency and working area. Besides, the Kampar Customary Institution (LAK) also plays a role in building communication and convincing the Regional Government, especially the Regent, LAM Riau, and the Riau Provincial Government. It plays a role in resolving territory conflicts.

The success of the collaboration is proved by a Regent Decree and direct support from the central government through the handover of a symbolic decree by President Joko Widodo in early 2020 and the submission of a Social Forestry Decree to the communities in Riau Province. This collaboration framework also reaches the stage of policymaking in the form of an academic paper and a draft of regional regulation on the Recognition and Protection of the Communities of National Customary Laws. This Draft of Regional Regulation is prepared considering that the state's existence as a customary law community in Kampar Regency is part of the social structure and a component of society that the state must recognize and respect. Therefore, the objectives of the recognition and protection of state customary law communities as stipulated in the Regional Regulation Draft are:

1. Providing protection and legal certainty for the existence of customary law communities, customary territories, and customary forests in Kenegerian in Kampar District

2. Strengthen and protect the rights of the National Customary Law Communities to access land, water, and natural resources that exist in their customary territories

3. Realizing the sustainable and sustainable management of customary territories based on customary law

4. Improving the welfare of the Kenegerian Customary Law Communities

5. Realizing development policies in the regions that recognize, respect, protect, and fulfill the rights of the National Customary Law Communities

6. Protect the value system that determines the Kenegerian's social, economic, political, cultural, and customary institutions

7. Realizing dispute resolution based on recognition and respect for the rights of the State Customary Law Communities and their customary law

The Draft Regulation on the Recognition and Protection of the Communities of National Customary Laws includes:

a. The Existence and Position of the State Customary Law Communities;

b. Customary Territories and Customary Forests

c. Customary Institution

d. Customary law

e. Registration Team for the Designation of Customary Law Communities, Customary territories, and Customary Forests

134 | Rury Febrina', Raja Muhammad Amin'2, Isril ${ }^{3}$, Ishak ${ }^{4}$ 
f. Customary Land Tenure and Utilization System

g. Duties and Authorities of the State Customary Law Communities

h. The Rights of Kenegerian in Customary Law Communities

i. Empowerment of Kenegerian Customary Law Communities

j. Dispute Handling

The main obstacle to the Draft of Regional Regulation is that it did not arrive at the stage of discussion, and the enactment of a regional regulation was more due to the incomplete verification process by the Ministry of Environment and Forestry. The Kampar Regency Regional Regulation status had not been revised, and the intense conflict of interest in recognition of indigenous people's rights and communal land rights. Besides, it is also necessary to encourage revisions to the Regional Regulation of Riau Province, namely Regional Regulation Number 10 of 2015 concerning Customary Communal Land and Its Utilization. This regional regulation is an entry point for recognizing and protecting communal land that covers the province. Besides, this collaboration has also been postponed due to several strategic and impactful events, such as the 2019 Legislative Election. Moreover, until now, it has not been processed again due to the COVID19 pandemic.

\section{CONCLUSION}

Recognition and protection of customary law communities in the Kampar Regency are necessary given customary law communities before this country was founded. The Regent of Kampar issued a progressive response through Regent Decree Number 660LH-IV.2/32 of 2018 concerning the Formation of a Registration Team for the Establishment of Customary Law Communities, Customary Areas, and Customary Forests in Kampar Regency. The registration team that came from the Regional Office elements of the regional government, the Land Office, academics, aspects of the Ministry, NGOs, and Customary Institutions showed a collaboration involving state actors and non-state actors. This collaboration succeeded in initiating recognition of customary law communities, customary territories, and customary law with the release of Head of District Decrees in several Kenegerian in the Kampar Regency. Collaborative governance in customary law communities, customary territories, and customary law in Kampar District is initiated by NGOs focusing on the environment and sustainable development. It includes WRI, Bahtera Alam, Pelopor Sehati Foundation, and AMAN Kampar and academics. They have succeeded in building trust as the primary key to collaboration with the Regional and Central Government. The collaboration built is still needed considering the dominance in the implementation of tasks, the unequal power/authority of all parties, conflicts of interest, political will from regional heads, and communication and coordination problems are still significant obstacles. This collaboration is still needed for an extended period, not only until the release of a decree on recognition and protection but until the implementation and evaluation of policies oriented towards the protection, empowerment, and facilitation of the life aspects of indigenous people integrated with sustainable development programs.

\section{ACKNOWLEDGEMENT}

We want to express our gratitude to the Rector of the Riau University and his staff and the Dean of Social and Political Sciences Faculty of Riau University and his staff. They have provided moral and material support for the implementation of this research activity. Besides, the authors would also like to thank the research informants from the Kampar Regency government, WRI, Bahtera Alam, AMAN Kampar, the Sehati Pelopor Foundation, and academic colleagues who have taken the time to provide thoughts and information regarding this research. Finally, thank you to the entire research team who took their time, energy, and thought to carry out research activities and complete the reports and outcomes of this research.

\section{REFERENCES}

Adrie. (2018). Konsep Reformasi Birokrasi Pelayanan Publik. Jurnal Aktual Justice, 3(1), 1-13. 
Amin, R. M., ' I., \& Febrina, R. (2016). Strategi Pemberdayaan Masyarakat Melalui Pengembangan Kapasitas Kelembagaan Kampung Adat Di Kabupaten Siak Provinsi Riau. Jurnal Ilmu Pemerintahan Nakhoda, 15(26), 65-77. https://doi.org/10.35967/jipn.v15i26.3844

Ansell, C., \& Gash, A. (2008). Collaborative governance in theory and practice. Journal of Public Administration Research and Theory, 18(4), 543-571. https://doi.org/10.1093/jopart/mum032

Asrida, Wan; Amin, Raja Muhammad; Marta, A. (2019). Bentuk-Bentuk Kekuasaan dalam Pemanfaatan Tanah Ulayat di Kabupaten Kampar. Nakhoda: Jurnal Ilmu Pemerintahan, 17(1), 39. https://doi.org/10.35967/jipn.v17i1.7057

Bingham, L. B., Nabatchi, T., \& O'Leary, R. (2005). The New Governance: Practices and Processes for Stakeholder and Citizen Participation in the Work of Government. Public Administration Review, 65(5), 547-558. http://www.jstor.org/stable/3542521

Dewi, R. T. (2012). Faktor-faktor yang Mempengaruhi Collaborative Governance dalam Pengembagan Industri Kecil (Studi Kasus Tentang Kerajinan Reyog dan Pertunjukan Reyog Di Kabupaten Ponorogo). 1-123.

Emerson, K., Nabatchi, T., \& Balogh, S. (2012). An Integrative Framework for Collaborative Governance. Journal of Public Administration Research and Theory: J-PART, 22(1), 1-29. http://www.jstor.org/stable/41342607

Huxham, C., \& Vangen, S. (2008). Doing Things Collaboratively: In J. O'Flynn \& J. Wanna (Eds.), Collaborative Governance (pp. 29-44). ANU Press. http://www.jstor.org/stable/j.ctt24h315.9

Maulana Mukhlis, Nasrullah Nazsir, Mudiyati Rahmatunnisa, N. Y. Y. (2018). Vol. 6, No. 3, September 2018. Jurnal Ilmiah Peuradeun, 6(3). https://doi.org/Jurnal Ilmiah Peuradeun | Copyright@C2018SCAD Independent, All Rights ReservedJURNAL ILMIAH PEURADEUNThe InternationalJournal of Social Sciencesp-ISSN: 2338-8617/ e-ISSN: 24432067www.journal.scadindependent.orgJIP published by SCAD Independent. All articles published in this journal are protected by copyright, licensed under a CC-BY-SA or an equivalent license as the optimal license for the publication, distribution, use, and reuse of scholarly works. Any views expressed in this publication are

Moleong, L. J. (2007). Metodologi Penelitian Kualitatif. PT Remaja Rosdakarya Offset.

O'Flynn, J. (2008). Elusive appeal or aspirational ideal? In J. O'Flynn \& J. Wanna (Eds.), Collaborative Governance (pp. 181-196). ANU Press. http://www.jstor.org/stable/j.ctt24h315.22

P.P, E., R, R., S, R., \& M, A. (2018). Tata Kelola Hutan Berbasis Masyarakat. In Collaborative Governance (Issue 1).

Salamat, Y. (2016). Pengaturan Mengenai Hak Atas Tanah Masyarakat Hukum Adat ( Studi Kasus Pengakuan Terhadap Hak Atas Tanah Masyarakat Hukum Adat Dayak Di Kalimantan Tengah ) (Case Study of Recognition of the Dayak Adat Law Community Land in. 411-420.

Sepriandi, S., \& Hussein, R. (2019). Faktor-Faktor yang Mempengaruhi Collaborative Governance dalam Penanganan Pekerja Migran Bermasalah di Kota Tanjungpinang. JPPUMA Jurnal Ilmu Pemerintahan Dan Sosial Politik Universitas Medan Area, 7(1), 81. https://doi.org/10.31289/jppuma.v7i1.2175 
Shergold, P. (2008). Governing through collaboration. In J. O'Flynn \& J. Wanna (Eds.), Collaborative Governance (pp. 13-22). ANU Press. http://www.jstor.org/stable/j.ctt24h315.7

Silvia, C. (2011). Collaborative Governance Concepts for Successful Network Leadership. State \& Local Government Review, 43(1), 66-71. http://www.jstor.org/stable/41303176

Silviana, A. (2019). Kebijakan Satu Peta (One Map Policy) Mencegah Konflik di Bidang Administrasi Pertanahan. Administrative Law and Governance Journal, 2(2), 195-205. https://doi.org/10.14710/alj.v2i2.195-205

Smith, D. (2008). From collaboration to coercion: In J. O'Flynn \& J. Wanna (Eds.), Collaborative Governance (pp. 75-92). ANU Press. http://www.jstor.org/stable/j.ctt24h315.14

Syofyan, A. (2015). Perlindungan Hak-Hak Masyarakat Adat Menurut Hukum Internasional. Fiat Justisia, 6(2), 1-19. https://doi.org/10.25041/fiatjustisia.v6no2.326

Wulandari, W., Suranto, \& Priyo Purnomo, E. (2019). Collaborative Government dalam Mewujudkan Inovasi Pelayanan. JIP (Jurnal Ilmu Pemerintahan) : Kajian Ilmu Pemerintahan Dan Politik Daerah, 4(1), 13-28. https://doi.org/10.24905/jip.4.1.2019.13-28 
Table 3. Stages of the Implementation of the Establishment of Customary Law Communities, Customary Areas, and Customary Laws in Kampar Regency

\begin{tabular}{|c|c|c|}
\hline No. & Activity & Supporting Documents and Parties Involved \\
\hline 1 & $\begin{array}{l}\text { Examining the requested area map using } \\
\text { overlay. }\end{array}$ & 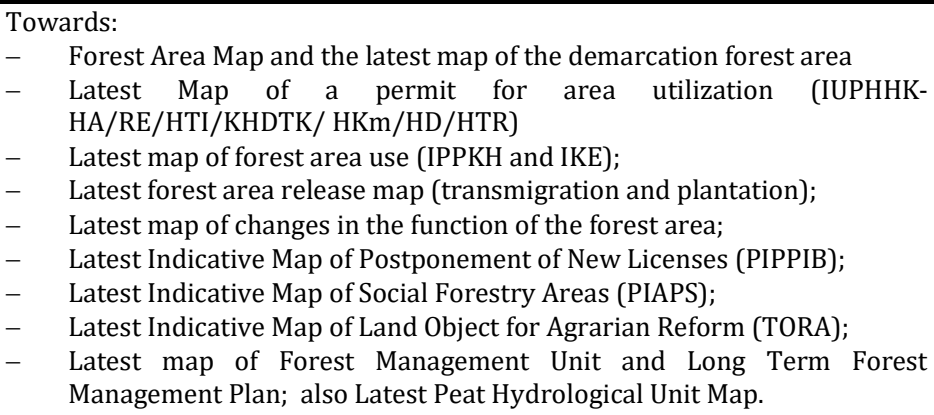 \\
\hline 2 & $\begin{array}{l}\text { Coordinating the implementation of } \\
\text { verification with local agencies to obtain } \\
\text { preliminary information on locations to } \\
\text { be technically verified }\end{array}$ & $\begin{array}{l}\text { The coordination is held together with Kampar Customary Institution, Camat, } \\
\text { and Forest Management Unit } \\
\text { The initial information needed is related to access to the location, the existence } \\
\text { of customary law communities, problems, conditions of forest cover, and so on }\end{array}$ \\
\hline 3 & $\begin{array}{l}\text { Implementing the Focus Group } \\
\text { Discussion (FGD) with proposers. }\end{array}$ & $\begin{array}{l}\text { Things covered in FGD: } \\
-\quad \text { Purpose and objectives of technical verification of customary forests; } \\
-\quad \text { Confirm the correctness of the application documents; } \\
-\quad \text { Confirmation of the correctness of customary law communities } \\
\text { institutions } \\
\text { - } \quad \text { Rights and obligations of indigenous peoples after receiving Stipulation } \\
\text { Decree } \\
-\quad \text { Dig up information about the prospective work area, which includes: } \\
-\quad \text { Efforts that have been done; } \\
-\quad \text { Potential areas, environmental services, non-timber forest products, } \\
\text { timber forest products; } \\
\text { - } \quad \text { Management plans; } \\
-\quad \text { Local wisdom on forest management; } \\
-\quad \text { Social, Economic, and Cultural conditions; } \\
\text { Access and distance to the location; } \\
\text { - The level of communities dependency on the requested location; } \\
-\quad \text { Customary territorial boundaries, customary forest and or village } \\
\text { administration; } \\
\text { If the proposed customary forest area has land cover in the form of } \\
\text { agriculture/plantation, it is necessary to confirm the owner, age of the } \\
\text { oil palm plantations, the location of the planted area and accompanied } \\
\text { by a statement letter from the manager; } \\
\text { if there is peatland, it is necessary to confirm the management plan and } \\
\text { complete it with a statement letter from the management. }\end{array}$ \\
\hline 4 & $\begin{array}{l}\text { Conducting field checks on the area } \\
\text { requested with the Global Positioning } \\
\text { System (GPS) tool to ensure the } \\
\text { suitability of facts, data, and information }\end{array}$ & $\begin{aligned} \text { About: } & \\
- & \text { The outer boundary of the prospective area location of Customary } \\
& \text { Territory and Customary Forest; } \\
- & \text { Administrative boundary; } \\
- & \text { Forestry permit limit and others; } \\
- & \text { Land Cover Hutan; } \\
- & \text { Topographic, slopes and elevations condition; } \\
- & \text { Dominant trees and plants. }\end{aligned}$ \\
\hline 5 & $\begin{array}{l}\text { Making an official report completed with } \\
\text { a map of the results of technical } \\
\text { verification signed by all team members }\end{array}$ & $\begin{array}{l}\text { As a material for recommendation to the Regent to issue a Regent Decree on } \\
\text { the determination of customary law communities, customary territories, and } \\
\text { customary law }\end{array}$ \\
\hline
\end{tabular}


Table 4. Establishment of Customary Law Communities and Proposed Customary Forests for Areas of Other Use (APL) and Forest Area

\begin{tabular}{|c|c|c|c|c|c|c|c|}
\hline No & $\begin{array}{l}\text { Name of } \\
\text { Proposed } \\
\text { Customary } \\
\text { Forest }\end{array}$ & $\begin{array}{l}\text { Village/ } \\
\text { District }\end{array}$ & $\begin{array}{l}\text { Regent } \\
\text { Decree }\end{array}$ & $\begin{array}{c}\text { Customary } \\
\text { Territory } \\
\text { Area }\end{array}$ & $\begin{array}{l}\text { Customary } \\
\text { Forest } \\
\text { Area }\end{array}$ & $\begin{array}{l}\text { Territor } \\
\text { y Use }\end{array}$ & Information \\
\hline 1 & $\begin{array}{l}\text { Kenegerian } \\
\text { Petapahan }\end{array}$ & $\begin{array}{l}\text { Petapahan/ } \\
\text { Tapung }\end{array}$ & $\begin{array}{l}\text { No: } \\
660491 / \mathrm{x} / 2 \\
018 \\
\text { Dated } \\
\text { October 16th, } \\
2018\end{array}$ & - & $251 \mathrm{Ha}$ & APL & $\begin{array}{l}\text { It has been } \\
\text { proposed to the } \\
\text { Ministry of } \\
\text { Environment } \\
\text { and Forestry } \\
\text { and has been } \\
\text { verified }\end{array}$ \\
\hline 2 & $\begin{array}{l}\text { Kenegerian } \\
\text { Kampa }\end{array}$ & $\begin{array}{l}\text { Kampa and } \\
\text { Koto } \\
\text { Perambaha } \\
\text { n/ Kampa }\end{array}$ & $\begin{array}{l}\text { No: 660- } \\
\text { 328/iv/2019 } \\
\text { Dated 5 April } \\
2019\end{array}$ & - & $157 \mathrm{Ha}$ & APL & $\begin{array}{l}\text { It has been } \\
\text { proposed to the } \\
\text { Ministry of } \\
\text { Environment } \\
\text { and Forestry } \\
\text { and has been } \\
\text { verified }\end{array}$ \\
\hline 3 & $\begin{array}{l}\text { Kenegerian } \\
\text { Batu Sanggan } \\
\text { Kekhalifahan } \\
\text { Batu Sanggan }\end{array}$ & $\begin{array}{l}\text { Batu } \\
\text { Sanggan/ } \\
\text { Kampar } \\
\text { Kiri Hulu }\end{array}$ & $\begin{array}{l}\text { No: } 660- \\
490 / \mathrm{X} / 2018 \\
\text { Dated } 16 \\
\text { October } 2018\end{array}$ & $5.863 \mathrm{Ha}$ & $641 \mathrm{Ha}$ & $\begin{array}{l}\text { Wildlife } \\
\text { reserve } \\
\text { Bukit } \\
\text { Rimbang } \\
\text { Bukit } \\
\text { Baling } \\
\end{array}$ & \multirow{5}{*}{$\begin{array}{l}\text { It has been } \\
\text { proposed to the } \\
\text { Ministry of } \\
\text { Environment } \\
\text { and Forestry but } \\
\text { has not been } \\
\text { verified }\end{array}$} \\
\hline 4 & $\begin{array}{l}\text { Kenegerian } \\
\text { Gajah } \\
\text { Bertalut } \\
\text { Kekhalifahan } \\
\text { Batu Sanggan }\end{array}$ & $\begin{array}{l}\text { Terusan/ } \\
\text { Kampar } \\
\text { Kiri Hulu }\end{array}$ & $\begin{array}{l}\text { No: } 660- \\
489 / \mathrm{x} / 2018 \\
\text { Dated } 16 \\
\text { October } 2018\end{array}$ & $4.414 \mathrm{Ha}$ & $4.414 \mathrm{Ha}$ & $\begin{array}{l}\text { Wildlife } \\
\text { reserve } \\
\text { Bukit } \\
\text { Rimbang } \\
\text { Bukit } \\
\text { Baling } \\
\end{array}$ & \\
\hline 5 & $\begin{array}{l}\text { Kenegerian } \\
\text { Aur Kuning } \\
\text { Kekhalifahan } \\
\text { Batu Sanggan }\end{array}$ & $\begin{array}{l}\text { Aur } \\
\text { Kuning/ } \\
\text { Kampar } \\
\text { Kiri Hulu }\end{array}$ & $\begin{array}{l}\text { No: 660- } \\
\text { 326/iv/2019 } \\
\text { Dated } 5 \text { April } \\
2019\end{array}$ & $8.103 \mathrm{Ha}$ & $1.827 \mathrm{Ha}$ & $\begin{array}{l}\text { Wildlife } \\
\text { reserve } \\
\text { Bukit } \\
\text { Rimbang } \\
\text { Bukit } \\
\text { Baling } \\
\end{array}$ & \\
\hline 6 & $\begin{array}{l}\text { Kenegerian } \\
\text { Terusan, } \\
\text { Kekhalifahan } \\
\text { Batu Sanggan }\end{array}$ & $\begin{array}{l}\text { Terusan/ } \\
\text { Kampar } \\
\text { Kiri Hulu }\end{array}$ & $\begin{array}{l}\text { No: 660- } \\
\text { 327/Iv/2019 } \\
\text { Dated 5 April } \\
2019\end{array}$ & $4.867 \mathrm{Ha}$ & $767 \mathrm{Ha}$ & $\begin{array}{l}\text { Wildlife } \\
\text { reserve } \\
\text { Bukit } \\
\text { Rimbang } \\
\text { Bukit } \\
\text { Baling } \\
\end{array}$ & \\
\hline 7 & $\begin{array}{l}\text { Pesukuan } \\
\text { Petopang } \\
\text { Kenegerian } \\
\text { Kuok }\end{array}$ & $\begin{array}{l}\text { Bukit } \\
\text { Melintang/ } \\
\text { Kuok }\end{array}$ & $\begin{array}{l}\text { No: 660- } \\
\text { 325/Iv/2019 } \\
\text { Dated } 5 \text { April } \\
2019\end{array}$ & $3.135 \mathrm{Ha}$ & $1.871,7 \mathrm{Ha}$ & $\begin{array}{l}\text { Nature } \\
\text { preserve } \\
\text { Bukit } \\
\text { Bungkuk } \\
\text { dan HPT } \\
\text { Batang } \\
\text { Lipai } \\
\text { Siabu }\end{array}$ & \\
\hline
\end{tabular}

Source: Expose Recognition Process of Customary Law Communities, Customary Areas, and Customary Forests in the District Kampar. September 16th, 2019. 